\title{
AUGUSTINE'S USE OF THE KK-THESIS IN THE CITY OF GOD, BOOK 11
}

\author{
JOSHUA ANDERSSON
}

Saint Louis University

\begin{abstract}
It seems odd that in such a densely theological text that Augustine would bring up something like the KK-thesis, which is so epistemological. Yet, as one progresses through the book it does begin to make sense. In this paper, I aim to try to come to some understanding of how and why Augustine uses something like the KK-thesis in Book 11 of The City of God. The paper will progress in the following way: First, I discuss Jaakko Hintikka's work on the KKthesis in order to have a clear idea of what the KK-thesis is, and some associated problems with it. Next, since Augustine most explicitly deals with the KK-thesis in De Trinitate, with the help of Gareth Matthews work, I discuss Augustine's use of the KK-thesis there. Finally, I return to The City of God, in order come to an understanding of Augustine's use of the KK-thesis there.
\end{abstract}

In Book 11 of The City of God Augustine explicitly begins his treatment of 'the origin and end of the two cities.' That being so, it seems odd that Augustine would bring up epistemological issues, at least on first blush. However, as one progresses through the book it does begin to make sense. What is of particular concern in this paper is Augustine's use of something like a KK-thesis at 11.26. The KK-thesis is the idea that if one knows, then one knows that one knows. There are, famously, some serious potential problems with the KK-thesis, issues that will be discussed below, but those are side issues for the purposes of this paper. Rather, in this paper, I aim to try to come to some understanding of how and why Augustine uses the KK-thesis in Book 11.

${ }^{1}$ Augustine, 'The City of God, Book 11', in The City of God: De Civitate Dei contra Paganos, trans. by Marcus Dods (Peabody, MA: Hendrickson Publishers, Inc., 2009), p. 310 . 
With the foregoing in mind, this paper will progress in the following way. In section I, in order to have a clear idea of what the KK-thesis is generally, and some of the associated problems with it, I discuss Jaakko Hintikka's work on the KK-thesis. In section II, since Augustine most explicitly, and thoroughly, deals with the KK-thesis in De Trinitate, with the help of Gareth Matthews work I discuss Augustine's use of the KKthesis there. Building on the previous two sections, in section III, I return to The City of God, in order come to an understanding of Augustine's use of the KK-thesis in Book 11.

I.

In this section, I will briefly present Hintikka's analysis of the KKthesis that he presents in Knowledge and Belief. After coming to a clear understanding of what Hintikka has to say, it will be suggested that, at least on Hintikka's account, the KK-thesis, far from being problematic, is in some sense trivial. However, there is the potential for an interpretation of the KK-thesis that could be problematic.

Setting aside the fact that, as Hintikka notes, the statement 'knowing that one knows that $p \ldots$ is [a] rather strange' ${ }^{2}$ thing to say, there is something, at least intuitively, that seems problematic about second order knowledge claims. What is valuable about Hintikka's discussion is that he shows that ' $[\mathrm{k}]$ nowing that one knows [is] virtually equivalent to knowing. ${ }^{3}$ What Hintikka means is that the two are logically equivalent, which can be proven as follows:

Let the statement $a$ knows that $\mathrm{P}$ be represented as KaP. Thus, $a$ knows that $a$ knows that $\mathrm{P}$ can be represented as KaKaP. To say that $\mathrm{KaP}$ is logically equivalent to $\mathrm{KaKaP}$ can be represented as $\mathrm{KaP} \leftrightarrow$ $\mathrm{KaKaP}$. Now, if Ka is taken as epistemic modal operator that functions equivalently to $\square$, then in a modal system at least as strong as $S 4$ it is true that $\mathrm{KaP} \leftrightarrow \mathrm{KaKaP}$.

(1) | KaP (by assumption)

(2) | KaKaP (1 by S4)

(3) $\mathrm{KaP} \rightarrow \mathrm{KaKaP}(1-2$ by $\rightarrow \mathrm{I})$

${ }^{2}$ Jaakko Hintikka, Knowledge and Belief: An Introduction to the Logic of Two Notions (Ithaca, NY: Cornell University Press, 1962), p. 104.

${ }^{3}$ Ibid. 
(4) $\mid \mathrm{KaKaP}$ (by assumption)

(5) $\mid \mathrm{KaP}(4$ by T)

(6) $\mathrm{KaKaP} \rightarrow \mathrm{KaP}(4-5$ by $\rightarrow$ I)

(7) $\mathrm{KaP} \leftrightarrow \mathrm{KaKaP}(3,6$ by $\leftrightarrow \mathrm{I})$

If $\mathrm{KaP}$ and $\mathrm{KaKaP}$ are logically equivalent, as has been shown, then the KK-thesis - which formally amounts to $\mathrm{KaP} \rightarrow \mathrm{KaKaP}$ - seems trivial. As Hintikka, himself, states: 'knowing that one knows "only differs in words from knowing"' ${ }^{4}$

However, the KK-thesis has a long history in philosophy, which Hintikka discusses, of being problematic. The problem, though, is not the result of mere logical equivalence - even if the solution might be. The problem is the introspective, or 'quasi-psychological's in Hintikka's words, implications of the KK-thesis. To be clear, there are two related problems with a KK-thesis: 1) it seems to entail infinite knowledge, and 2) the problem of cognitive ascent. As to the first, if $\mathrm{KaP} \rightarrow \mathrm{KaKaP}$, then $\mathrm{KaKaP} \rightarrow \mathrm{KaKaKaP}$, and this can continue ad infinitum, then any knowledge claim implies, and perhaps even necessarily entails, that there is an infinite number of things that one knows - knowing that $\mathrm{P}$ is one thing, knowing that one knows is a second et cetera. For some, such infinite knowledge is prima facie problematic, because the human mind, or so it would seem, is incapable of such infinite knowledge.

Now, as to the problem of cognitive ascent, understood logically, the KK-thesis 'need not mean that one is performing whenever one knows something, another act of self-observation.6 ${ }^{6}$ But, understood introspectively, the KK-thesis would mean that one is performing another, and infinitely many, acts of knowing, and that does seem to be a problem - this is the problem of cognitive ascent. There are actually two related problems with cognitive ascent. First, each iteration of the KK-thesis is a higher-order knowledge claim, so not only does one have an infinite amount of knowledge but each claim is qualitatively different. Second, assuming that iterations of the KK-thesis, understood introspectively, requires the passage of time then for any act of knowing it would entail that the mind would be occupied for an infinite amount of time.

\footnotetext{
${ }^{4}$ Ibid., p. 111.

${ }^{5}$ Ibid.

${ }^{6}$ Ibid.
} 
There is an issue that needs to be addressed at this point. Hintikka's logical analysis of the KK-thesis does not seem to do justice to what the problem really is. It does not seem that the statements 'I know that P' and 'I know that I know that $\mathrm{P}^{\prime 7}$ mean the same thing. Thus, presupposing the introspective view, KaP implies one kind of act and KaKaP implies a different act, even if it is of the same kind. Hintikka can freely acknowledge the difference in meaning without conceding anything to the introspective perspective - remember it is the introspective interpretation of the KK-thesis that seems to lead to problems. As an issue of pragmatics $\mathrm{KaP}$ and $\mathrm{KaKaP}$ might have different connotations, but as a matter of fact 'all those circumstance which would justify one in

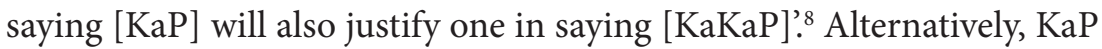
and $\mathrm{KaKaP}$, while being logically equivalent, again can connote different things, for example when uttered, $\mathrm{KaKaP}$ indicates 'that the person in question is aware that he is in a position to know's or that 'he feels certain [...] that he knows. ${ }^{10}$ These connotations, however, are what Hintikka calls 'residual meanings' ${ }^{11}$ and should not be confused with the real epistemic issues.

There are many other matters that Hintikka discusses relating to the KK-thesis, and, of course, Hintikka's analysis and considered responses are more nuanced than presented here. However, the point of this section was to give an idea of what Hintikka had to say regarding the KK-thesis. What has been discussed, though, will be sufficient for the purposes of this paper, and the discussion of Augustine.

II.

As has been noted, Augustine discusses the KK-thesis and related matters not just in The City of God, but also in De Trinitate. I will return to Augustine's use of the KK-thesis in The City of God, below. However, since the use of the KK-thesis is most fully explained in De Trinitate and much of the secondary literature relates to its use there, by getting clear

\footnotetext{
${ }^{7}$ For simplicity I will use 'KaP' and 'KaKaP' as stand-ins for the phrases 'I know that $\mathrm{P}$ ' and I know that I know that P', respectively.

${ }^{8}$ Hintikka, Knowledge and Belief, p. 111.

${ }^{9}$ Ibid., p. 114.

${ }^{10}$ Ibid.

${ }^{11}$ Ibid., p. 121.
} 
on Augustine's use in De Trinitate one can then return to The City of God, in a better position to understand its use and purpose there. Thus, what will be discussed in this section of the paper is Augustine's response to scepticism as presented in book 15 of De Trinitate. It will be shown that it does appear that Augustine is asserting something like the KK-thesis to iterate knowledge claims to show that, contrary to what the sceptic believes, one does have a great deal of knowledge. The work of Gareth Matthews will be helpful in coming to understand: 1) whether or not Augustine is using the KK-thesis, and 2) what Augustine's purposes are for introducing, at least, a KK-like-thesis.

As was just mentioned, Augustine in Book 15 of De Trinitate introduces something like a KK-thesis as a way to establish that, despite what the sceptic claims, there is a great deal that one does in fact know. It is worth quoting Augustine at length to make this point clear:

The knowledge by which we know that we are alive is most intimately inward, and cannot be touched by an Academic [sceptic] ... So someone who says he knows he is alive can never be lying or be deceived. Let a thousand kinds of illusion be objected against the man who says 'I know I am alive'; none of them will worry him, since even the man who suffers from an illusion is alive.

But if this is the only kind of thing that really pertains to human knowledge, then there are extremely few instances of it - except that any point of knowledge can be so multiplied that its instances, far from being few, turn out to extend to infinity. Thus the man who says 'I know I am alive' says he knows one thing: but if he says 'I know that I know I am alive', there are two things. The fact that he knows these two things makes a third knowing; and in this way he can add a fourth and a fifth and a countless number more, if he has the time. But because he cannot either comprehend an innumerable number by adding up single ones or give it innumerable expression, what he certainly does comprehend is both that this is true, and that it is so innumerable that he cannot comprehend or express the infinite number of its word. ${ }^{12}$

So, there are two things which Augustine is articulating in the above quote. First, Augustine is establishing that there is at least one piece of knowledge that one can have that is completely immune to scepticism viz. 'I know that I am alive.' Thus, like Descartes even if one is dreaming

12 Augustine, 'De Trinitate, Book 15', in The Trinity: De Trinitate, ed. by John E. Rotelle (Hyde Park, NY: New City Press, 1991), p. 412. 
or is being deceived one can still know that one is alive to be dreaming or deceived. 'I am alive' here should be construed very broadly to mean roughly that 'I exist' as Gareth Matthews has pointed out. ${ }^{13}$ However, Augustine rightly acknowledges that if that was all one could know, it would not be much of a response to the sceptic, and therefore goes on to articulate how, based on 'I know that I am alive' there are in fact many things that one knows.

In order to establish that there are many things one knows, it seems that Augustine is putting forward a KK-thesis. Thus, Augustine states that since I know that I am alive - let that be represented as KaP, where $\mathrm{P}$ stands for 'I am alive', and Ka stands for 'I know that' - it does not seem to be a stretch to establish that KaKaP. That is to say, from KaP one derives $\mathrm{KaKaP}$, or $\mathrm{KaP} \rightarrow \mathrm{KaKaP}$. Roughly then, it seems that Augustine seems to be positing something like epistemic closure under known entailment - i.e. if $S$ knows that $\mathrm{p}$, and $\mathrm{p}$ entails $\mathrm{q}$, then $\mathrm{S}$ knows that q. Basically, the second knowledge claim, KaKaP, follows from modus ponens and the fact that knowledge - at least some knowledge - is closed under known entailment. ${ }^{14}$ Formally, Augustine can be seen as arguing, implicitly, as follows:

(1) $\mathrm{KaP} \rightarrow \mathrm{KaKaP}$ (known entailment)

(2) $\mathrm{KaP}$ (established by argument)

(3) $\mathrm{KaKaP}$ (1, 2 modus ponens)

There is an open question of how Augustine comes to believe that $\mathrm{KaP}$ $\rightarrow \mathrm{KaKaP}$ is true. Perhaps he believes that it just naturally falls out of any adequate definition of knowledge - which seems to be exactly what Hintikka had in mind. Alternatively, Augustine might be confusing the claim 'I am certain that P' with KaKaP, and has thus inappropriately established $\mathrm{KaP} \rightarrow \mathrm{KaKaP}$. Augustine could also be introducing the introspective perspective that Hintikka was worried about, and at pains to dismiss. To take Augustine in this last way would be to say that if $\mathrm{KaP}$, and one reflects on what $\mathrm{KaP}$ really means, then one will see that KaKaP. To understand Augustine along this introspective/reflective model would suggest that the modus ponens argument is actually just

${ }^{13}$ Gareth B. Matthews, Augustine (Malden, MA: Blackwell Pub., 2005), p. 40.

${ }^{14}$ We can bracket for now the criticisms of epistemic closure, since many of them claim that closure fails because of global scepticism. But the antecedent in this case is immune from scepticism eo ipso anything that would logically follow from it would at least appear to be immune as well. 
an approximation of Augustine's view, but, even so, Augustine must certainly be asserting something like the KK-thesis even if it is not one of logical entailment.

From establishing $\mathrm{KaP}$ and $\mathrm{KaP} \rightarrow \mathrm{KaKaP}$, Augustine can then be understood to be multiplying one's knowledge by repeated iterations of the KK-thesis. Thus, from $\mathrm{KaP}$ and $\mathrm{KaP} \rightarrow \mathrm{KaKaP}$, one goes on to establish that KaKaP, KaKaKaP, and so on ad infinitum. For Augustine, then, he believes that he has proven that far from having no knowledge, as the sceptic contends, humanity actually has an infinite amount of knowledge, even if humanity is unable to express it. ${ }^{15}$

In his book on Augustine, ${ }^{16}$ Gareth Matthews takes Augustine to task precisely for using the KK-thesis, as has been presented thus far, as a way to refute the sceptics that would deny humanity knowledge. Regardless of whether or not the initial claim that $\mathrm{KaP}$ can be established and is true, Matthews believes that there are at least three difficulties with the iteration of knowledge claims that arise from the application of the KKthesis. First, if $\mathrm{KaKaP}$ is, as Hintikka takes it to be, virtually equivalent to $\mathrm{KaP}$, 'then the multiplication of knowledge claims may be only an illusion, each iteration being virtually equivalent to its predecessor. ${ }^{17}$ Second, even if the KK-thesis is valid for first-person 'I claims', there does seem to be problems with 'third-person instantiations of the KK-[thesis]. Jane may know that $p$, but not know that Jane knows that $p$ because she does not know that she is Jane. ${ }^{18}$ Third, even if KaP one might be frustrated by the fact that there is a lack of consensus about what it takes for one to know, and therefore KaKaP fails to obtain because one is sceptical about what the conditions for knowledge are. As Matthews states:

[i]f I know anything, and surely I do know something, I know that I exist. But to know that I know I exist I must also, it may well seem know what are the necessary and sufficient conditions for knowing something. And this I do not know. ${ }^{19}$

However, Matthews only mentions these in passing before moving on to the more important point of Augustine's purposes for his repeated iterations of knowledge. Unlike Descartes who wanted to 'begin again from the original foundations [...] [in order] to establish anything firm

\footnotetext{
${ }^{15}$ I will return to Augustine on humanity's infinite knowledge below.

${ }^{16}$ Matthews, Augustine.

${ }^{17}$ Ibid., p. 41.

18 Ibid.

${ }^{19}$ Ibid.
} 
and lasting in the sciences, ${ }^{20}$ 'Augustine has here no ambition whatsoever to provide a rational reconstruction of all he knows on the indubitable foundation of "I exist"." 21 According to Matthews, Augustine's purpose is to highlight 'an inner realm of knowledge each of us has open to us', ${ }^{22}$ which by its very nature is immune to scepticism.

Since 2005, Matthews has changed his views about Augustine and his use of the KK-thesis in two important ways. First, Matthews suggests that Augustine was actually using something different, though similar to, the KK-thesis to multiply human knowledge. Second, Matthews has put more emphasis on Augustine's project in De Trinitate such that he has realized that Augustine was less concerned with responding to the sceptic and more concerned with establishing an image of God in the mind of man.

Matthews begins his (re-)analysis of Augustine by pointing out that where it appears Augustine is using the KK-thesis to multiply knowledge - i.e. from $\mathrm{KaP}$ and $\mathrm{KaP} \rightarrow \mathrm{KaKaP}$ one can go on, by repeated iterations to $\mathrm{KaKaP} \rightarrow \mathrm{KaKaKaP}$ and $\mathrm{KaKaKaP}$, and so on out to infinity - Augustine is not using logical entailment or material implication to multiply said knowledge. Rather, Augustine is actually multiplying knowledge by forming conjunctions. Matthews believes the conjunction reading is more accurate because after Augustine has established $\mathrm{KaP}$ and $\mathrm{KaKaP}$ he says: 'Iam hoc vero quod scit haec duo tertium scire est, which, in a rather clunky literal translation says, Now this that he surely know these two, is to know a third thing. ${ }^{.23}$ It is useful to quote Matthews at length here:

It seems, then, that what Augustine has in mind is the following. Suppose I know that I'm alive. Let's call what I know when I know this 'K1.' Then let's call what I know when I know that I know K1 'K2.' Now Augustine says, in knowing $\mathrm{K} 1$ and also knowing $\mathrm{K} 2 \mathrm{I}$ know a third thing, namely, the conjunction of $\mathrm{K} 1$ and $\mathrm{K} 2$, which we can call ' $\mathrm{K} 3$ '. But then I can know not only K1, K2, and K3, but also a fourth thing, the conjunction

${ }^{20}$ Rene Descartes, 'Meditations on First Philosophy', in Discourse on Method and Meditations on First Philosophy. 3rd edition, trans. by Donald A. Cress (Indianapolis, IN: Hackett Publishing Company, 1993), p. 59.

${ }^{21}$ Matthews, Augustine, p. 42.

22 Ibid.

${ }^{23}$ Gareth Matthews, 'Skepticism and Knowledge in Augustine's De Trinitate' (paper presented at Mind and the Structure of Reality: A Conference on Augustine's De Trinitate, Cornell University, Ithaca, NY, September 28-29, 2007), p. 10. 
of these three, which we can call ' $\mathrm{K} 4$ ', and so for innumerable cases 'if one should be up to it' (si sufficiat). Let's call this result 'the Multiplication Thesis', and contrast it with what we can call the 'Iteration Thesis', which is the result of successive applications of the KK-[thesis]. ${ }^{24}$

Thus, according to Matthews instead of epistemic closure under known entailment, Augustine is putting forward, something like, epistemic closure under conjunction. Granted, Matthews is unsure how Augustine moves from the first-order claim that $\mathrm{KaP}$ to the second-order claim that $\mathrm{KaKaP}$, but once Augustine does the rest follows naturally. It should also be pointed out that si sufficiat is integral to the argument. Because of that caveat, Augustine is not committed to cognitive ascent, with the regress problems that arise regarding it. Augustine is pointing out that the mind could, given an infinite amount of time, know an infinite number of things, but it is just that the mind has the potential to do so, not that the mind actually has to, or does do so.

The second thing, which Matthews takes note of, that he failed to in 2005, is that the purpose of De Trinitate is to show that there is an image of God in the mind(s) of humanity. By taking Augustine seriously here, one is better able to understand how the Multiplication Thesis - the KKlike-thesis - is to function for Augustine. It is not merely the refutation of scepticism; rather Augustine wants his readers to delight in the power of the mind insofar as it is an image of God.

So, first, because humanity is able to multiple its knowledge, potentially infinitely, with the Multiplication Thesis, Matthews maintains that Augustine

wanted us, his readers, to thrill at the idea of infinite mental iteration [or multiplication]. [...] Perhaps the idea that we can infinitely [multiply] some or all of our knowledge claims would tell us something interesting and important about ourselves, or about our minds, that would fit into Augustine's more general project in De Trinitate. ${ }^{25}$

Second, according to Augustine, nothing is so present to the mind as the mind itself, ${ }^{26}$ and since the mind cannot even comprehend its own ability - viz. the ability to have infinite knowledge - the mind is thus a fitting image of the divine. '[I]n the incomprehensibility of our

24 Ibid.

${ }^{25}$ Ibid., p. 9.

${ }^{26}$ Augustine, 'De Trinitate, Book 10', in The Trinity: De Trinitate, ed. by John E. Rotelle (Hyde Park, NY: New City Press, 1991), p. 297. 
own minds to ourselves [we find] a reflection of the vastly greater incomprehensibility of God. ${ }^{27}$ Thus, Augustine introduces his KK-likethesis 'to bring us closer to God by helping us appreciate another respect in which our own minds are images of the Divine mind. ${ }^{28}$

The purpose of this section was to make clear how Augustine uses something like the KK-thesis in De Trinitate. Since De Trinitate is Augustine's most explicit use of something like the KK-thesis, and since he was working on De Trinitate while also working on The City of God, by getting clear on Augustine's use of something like the KK-thesis in the former a better understanding of his use of something like the KK-thesis in the latter can be had.

III.

In this section of the paper, I turn to The City of God, and to Augustine's use of the KK-thesis there, in an effort to try to come to some understanding of how and why Augustine uses the KK-thesis. This section builds on the previous two sections, it will be shown, or at least suggested, that although there are clear similarities between Hintikka - which will not be discussed explicitly - and Augustine's use of something like the KK-thesis in De Trinitate and The City of God, there are also important differences. Since Hintikka, Matthews and Augustine in De Trinitate, seem to have answers to the problematic nature of the KK-thesis - e. g. its implications for infinite knowledge and cognitive ascent - there is little reason to discuss these issues in this section.

In the previous section, there were two main conclusions drawn regarding Augustine's use of something like the KK-thesis in De Trinitate. First, it was suggested that Augustine wants his reader to delight in the mind and its abilities insofar as it is an image of the divine. Second, by demonstrating the partial incomprehensibility of the mind, Augustine was also demonstrating the majesty of God of whom the mind is an image. Now, the explicit purpose, or at least one of the purposes, of De Trinitate is to show how humanity can be understood to be made in the image of a Trinitarian God. Similarly, in Book 11 of The City of God in chapters 24 through 28, Augustine is discussing the Trinitarian nature

${ }^{27}$ Matthews. 'Skepticism and Knowledge in Augustine's De Trinitate', p. 27.

28 Ibid. 
of God and 'its presence scattered everywhere among its works,, ${ }^{29}$ and then in chapter 26, in particular, Augustine is discussing 'the image of the supreme Trinity, which we find in some sort in human nature. ${ }^{30}$ This obvious similarity of the contexts in which the KK-thesis, or something like it, as discussed in each of Augustine's works - viz. De Trinitate and The City of God - might lead one to hastily conclude that Augustine's use of the KK-thesis in De Trinitate can be directly mapped on to his use in The City of God. I discuss, and give, textual support from Book 11 of The City of God that will demonstrate that there is reason to think that Augustine might want his readers to draw the same conclusions about God and the mind that he wants his readers of De Trinitate to draw. However, there are important differences in Augustine's use of something like a KK-thesis, and even the broader context of, Book 11 which leads to different, or additional, conclusions about Augustine's use of the KK-thesis in The City of God. Textual support will also be given for these additional conclusions.

I now turn to some textual support for the idea that Augustine wants his readers to draw similar conclusions from his use of the KK-thesis in Book 11 of The City of God and his use of the KK-thesis in De Trinitate. Again, in De Trinitate Augustine wants his reader to delight in the power of the mind and how much greater God is than man, who is made in his image.

Of course Augustine establishes that man is made in the image of God. Augustine states: 'And we indeed recognize in ourselves the image of God, that is of the supreme Trinity, an image which, though it be not equal to God. ${ }^{31}$ This quote clearly shows that not only is man an image of God, but also inferior to God. Moreover, it is the mind, or something like the mind, which is where the image of God is most present, as when Augustine claims that ' $\mathrm{f}$ ] or since man is most properly understood [...] to be made in God's image, no doubt it is that part of him by which he rises above the lower parts he has in common with beasts, which brings him nearer the Supreme[, i.e.] [...] the mind itself.' 32

Further, since according to Augustine, 'the knowledge of the creature is, in comparison of the knowledge of the creator but a twilight, ${ }^{33}$

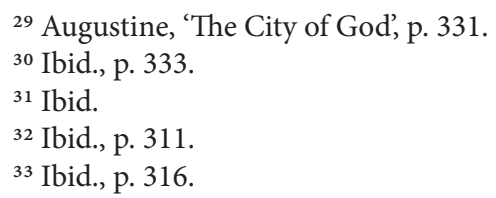


Augustine is again establishing how much greater God's powers and abilities are compared to the powers, abilities and intellectual capacities of the human mind. Even though humanity, and its mental capacity, pale in comparison to that of God, Augustine still wants his reader to 'delight in our being, and our knowledge of it. ${ }^{34}$

Granted, none of the above quotes speak directly to the KK-thesis, or Augustine's use of it. What is of importance is that Augustine wants his reader to come to the same, or similar, conclusions regarding humanity, and its mind and knowledge, and the nature of God and his knowledge in both De Trinitate and Book 11 of The City of God. On the other hand, the anti-sceptical conclusions that Augustine establishes with the KKthesis in the De Trinitate are also explicitly present in Book 11. First, Augustine begins with the indubitable piece of knowledge that he knows that he exists, and thus he is 'not at all afraid of the arguments of the Academicians, ${ }^{35}$ i.e. the sceptic. Then, based on this piece of knowledge, Augustine adds more knowledge by application, or iterations, of something like a KK-thesis. For example, 'I am most certain [know] that I am, and that I know and delight in this, ${ }^{36}$ or again 'neither am I deceived in knowing that I know [...] [f] or as I know that I am, so I know this also, that I know. ${ }^{37}$ In other words, if 'KaP' stands in for 'I know that I am', then Augustine is explicitly claiming that 1$) \mathrm{KaP} \rightarrow \mathrm{KaKaP}$ - i.e. he has something like a KK-thesis in mind - and 2) he is using it to refute the sceptic - i.e. the Academic.

There are clearly parallels between Augustine's thinking, in general, and his use of the KK-thesis, and philosophy of mind, in particular, in De Trinitate and Book 11 of The City of God. Most importantly, that while man is made in the image of God, it is in humanity's mind that this image is present. Further, Augustine wants to establish the majesty and, in some ways, the incomprehensibility of God, particularly in relation to humanity and its intellectual powers. Finally, Augustine is using something like the KK-thesis, to iterate and expand man's knowledge, and to respond to the sceptic, though in both works responding to the sceptic is not Augustine's main concern. However, there are also some important differences between Augustine's use of something like the

\footnotetext{
${ }^{34}$ Ibid., p. 333.

${ }^{35}$ Ibid.

${ }^{36}$ Ibid.

37 Ibid.
} 
KK-thesis, and the issues surrounding it, in De Trinitate and Book 11 of The City of God, and it is to those differences I now turn.

I think that the conclusions discussed above are all correct, and there is no reason to think that Augustine did not have those things in mind when he was writing The City of God, in fact I believe I have shown there is at least some reason to think that he did. However, by looking closely at Book 11 there are important things that can be learned regarding Augustine's use of the KK-thesis in The City of God, that are different from his use in De Trinitate.

What is particularly distinctive about the use of the KK-thesis in Book 11 is that Augustine only, for lack of a better term, iterates knowledge once - i.e. he only asserts $\mathrm{KaP} \rightarrow \mathrm{KaKaP}$ - and then stops. In De Trinitate Augustine states:

But if this is the only kind of thing that really pertains to human knowledge, then there are extremely few instances of it - except that any point of knowledge can be so multiplied that its instances, far from being few, turn out to extend to infinity. Thus the man who says 'I know I am alive' says he knows one thing: but if he says 'I know that I know I am alive, there are two things. The fact that he knows these two things makes a third knowing; and in this way he can add a fourth and a fifth and a countless number more, if he has the time. ${ }^{38}$

In contrast, in Book 11 Augustine only claims 'I am most certain [know] that I am, and that I know and delight in this, [...] neither am I deceived in knowing that I know [...] [f] or as I know that I am, so I know this also, that I know. ${ }^{39}$

There are at least two possible implications of this difference. First, it seems that Augustine in The City of God is much less concerned with responding to the sceptic. Second, in The City of God, Augustine seems more concerned with downplaying, as opposed to elevating, the abilities, powers, and standing of humanity, as compared with God.

As to the first, in The City of God, in general, and Book 11, in particular, Augustine's project is more explicitly metaphysical, and theological - in the sense of his concern with salvation, sin, the city of God, et cetera. Thus, the sceptic is less a part of the conversation than he might be in De Trinitate, which of course is also theological, but has

${ }^{38}$ Augustine, 'De Trinitate', p. 412.

${ }^{39}$ Augustine, 'The City of God', p. 333. 
much more to say about the philosophy of mind, and questions about epistemology. Further, throughout Book 11, Augustine actually spends a significant amount of time pointing out that humans are incapable of attaining knowledge, of at least certain things on their own. For example, Augustine states that

the Scripture which is called canonical, which has paramount authority, and to which we yield assent in all matters of which we ought not to be ignorant, and yet cannot know of ourselves. For if we attain the knowledge of present objects by the testimony of our own senses, whether internal or external, then regarding objects remote from our own, and we credit the persons to whom the objects have been or are sensibly present. Accordingly, as in the case of visible objects which we have seen, we trust those who have (and likewise with all sensible objects), so in the case of things which are perceived by the mind and spirit, that is which are remote from our own interior sense, it behooves us to trust those who have seen them set in that incorporeal light or abidingly contemplate them..$^{40}$

Thus, it seems incongruous for Augustine to, on the one hand, revel in man's (potentially) infinite knowledge, while drawing attention to the fact that there are many things man cannot know, at least without assistance of another - and this of course relates also to the second point, viz. that in The City of God, Augustine seems more concerned with downplaying, as opposed to elevating, the abilities, powers, and standing of humanity, as compared with God.

Related to the above quote, at 11.26, Augustine discusses how man comes to know sensible things, which is 'by some bodily sense [...] colours, for example, by seeing, sounds by hearing, smells by smelling, tastes by tasting, hard and soft objects by touching. ${ }^{41}$ Thus, Augustine is, in some ways, taking it for granted that the sceptic is wrong, and instead of building up human knowledge simply out of the raw intellectual abilities of a single thinking subject - as Descartes tried to do - Augustine is telling the reader the very many ways one can come to know a variety of things. Not only can one know a great many things simply by iterations of something like a KK-thesis, one can come to know based on sense experience, the testimony of other humans, and the testimony of the canonical scriptures.

\footnotetext{
${ }^{40}$ Ibid., p. 312.

${ }^{41}$ Ibid., p. 333.
} 
Again, however, Augustine does not want to build up humanity's intellectual/epistemological abilities too much, particularly vis-à-vis God. Thus, Augustine draws attention to the fact that 'we indeed recognize in ourselves the image of God, that is, of the supreme Trinity, though it be not equal to God, or rather, though it be very far removed from Him - being neither coeternal, nor, to say all in a word, consubstantial with Him.'42

Before moving on to another unique aspect of Augustine's use of something like a KK-thesis in Book 11, there is one additional issue to be brought up regarding the KK-thesis as a response to the sceptic. Notice that Augustine has said that 'I am most certain that I am, and that I know and delight in this. ${ }^{43}$ This quote can be taken in two ways. Either one is certain that one knows that one exists, and knows, and delights in, that one is certain. Alternatively, one is certain that one exists, one is certain that one knows that one exists, and one is certain that one delights in one's existence. On either interpretation there is an important clue as to how Augustine is thinking about the KK-thesis. Unlike Hintikka, who, at least at times, suggested that knowing that one knows might, as a matter of pragmatics, just be another way of saying that one is certain, for Augustine knowing that one knows and being certain clearly come apart. Thus, taking what Augustine says in De Trinitate and in Book 11 of The City of God, Augustine's KK-like-thesis seems fairly distinctive. Leaving aside the conjunctive aspect of the KK-thesis in De Trinitate, Augustine seems clear that an iteration of the KK-thesis is neither collapsible into a mere linguistic issue, nor does it commit Augustine to cognitive ascent - i.e. KaKaP is not necessarily a second-order knowledge claim. Therefore, some of the problematic aspects of a KK-thesis do not occur for Augustine.

The most interesting aspect of Augustine's use of a KK-like-thesis in The City of God is the non-epistemic application, or reinterpretation, of the KK-thesis. As was mentioned above, in De Trinitate Augustine states that: 'the man who says "I know I am alive" says he knows one thing: but if he says "I know that I know I am alive", there are two things. The fact that he knows these two things makes a third knowing; and in this way he can add a fourth and a fifth and a countless number more, if he has

${ }^{42}$ Ibid. emphasis added.

${ }^{43}$ Ibid. emphasis added. 
the time. ${ }^{34}$ However, in The City of God Augustine, as I have said, stops after the first iteration - i.e. with the claim of knowing that one knows. Augustine actually does not stop the iterations, but the iteration takes on a non-epistemic aspect. So, Augustine claims that 'as I know that I am, so I know this also, that I know', ${ }^{45}$ the straightforward KK iteration of knowledge, but then he goes on to say that '[a]nd when I love these two things [his existence, or being, and his knowledge], I add to them a certain third thing, namely my love, which is of an equal moment. ${ }^{46}$

Not only is Augustine departing from the KK-thesis, the second iteration being a love claim, not a knowledge claim, he is also adding a distinctively metaphysical/ontological flavour. Notice that in the above quote Augustine states that his existence and his knowledge is of an equal moment ${ }^{47}$ with his love. In other words, one's existence and knowledge and love are basically the same thing, yet different and mutually interact and support each other. Thus, at the end of 11.27 Augustine states that: 'I am assured that I am, and that I know this; and these two I love, and in the same manner I am assured that I love them.' 48 That is to say one's knowledge and love exist, one's existence is known and loved and one's love and existence is known, they are all of a piece, which is a kind of Trinitarian doctrine of the self.

So, although Augustine discusses something like a KK-thesis to talk about the Trinitarian image of God in man in both De Trinitate and The City of God, in The City of God, Augustine is using it - i.e. the KK-thesis explicitly to try to understand the nature of the Trinity, particularly as it is in man. Augustine says as much when he converts the KK-thesis into what might be called an LL-thesis - i.e. If one loves, then one loves that one loves, or LaP $\rightarrow \mathrm{LaLaP}$, where $\mathrm{P}$ can stand for either one's existence, knowledge or love of all three or any combination of two. Augustine asks rhetorically at $11.28^{\text {' }} \mathrm{w}$ w hether we ought to love the love itself with which we love our existence and our knowledge of it, that so we may more nearly resemble the image of the divine Trinity. ${ }^{49}$ However, in asking and answering this question Augustine wants to be clear that humanity's Trinitarian nature is but an inferior image of the divine nature, while at

\footnotetext{
${ }^{44}$ Augustine, 'De Trinitate', p. 412.

${ }^{45}$ Augustine, 'The City of God', p. 333.

${ }^{46}$ Ibid.

${ }^{47}$ Ibid.

${ }^{48}$ Ibid., p. 335.

${ }^{49}$ Ibid.
} 
the same time raising humanity up by reaffirming that man is capable of coming to at least a close approximation of an understanding of these things through its own power - limited though it may be. I quote Augustine at length to make this last point.

But we are men, created in the image of our Creator, whose eternity is true, and whose truth is eternal, whose love is eternal and true, and who Himself is the eternal, true, and adorable Trinity, without confusion, without separation; and, therefore, while as we run over all the works which He has established, we may detect, as it were, His footprints, now more and now less distinct even in those things that are beneath us, since they could not so much as exist, or be bodied forth in any shape, or follow and observe any law, had they not been made by Him who supremely is, and is supremely good and supremely wise; yet in ourselves beholding His image, let us, like that younger son of the gospel, come to ourselves, and arise and return to Him from whom by our sin we had departed. There our being will have no death, our knowledge no error, our love no mishap. But, now, though we are assured of our possession of these three things, not on the testimony of others, but by our own consciousness of their presence, and because we see them with our own most truthful interior vision, yet, as we cannot of ourselves know how long they are to continue, and whether they shall never cease to be, and what issue their good or bad use will lead to, we seek for others who can acquaint us of these things, if we have not already found them. ${ }^{50}$

In this section of the paper, I have tried to come to some understanding of Augustine's use of something like the KK-thesis, and the role that it plays in The City of God, particularly in Book 11. It was shown that there is textual support for believing that Augustine's understanding of something like a KK-thesis in The City of God is consistent with his understanding and use of something like the KK-thesis in De Trinitate. However, there is also textual support for a richer, more metaphysical/ ontological and theological, and less epistemic use and purpose of a KKlike-thesis that is distinctive in The City of God.

In both works Augustine is concerned with trying to create a sense of wonder both for humanity's mind, and God's majesty, and also with responding to the sceptic. In The City of God, however, these aspects are less important than the metaphysical/ontological implications of the KKthesis' use. In particular, in The City of God, Augustine uses something

${ }^{50}$ Ibid., pp. 335-6. 
like the KK-thesis to help his reader better understand the Trinitarian nature of the image of God in humanity. Finally, although the KK-thesis has been criticized for leading to potential, primarily epistemological, problems, such as cognitive assent, Augustine's use of something like the KK-thesis avoids these problems without resorting to the deflationary logico-linguistic strategy of someone like Hintikka.

IV.

To conclude, in this paper I have tried to come to some understanding of Augustine's use of something like a KK-thesis in Book 11 of The City of God. I began by reviewing Jaakko Hintikka's work on the KK-thesis as a way to introduce the idea, point out some of the potential pitfalls of the KK-thesis and as a foil to show the distinctiveness of Augustine's view. Since Augustine also presents something like a KK-thesis in De Trinitate, his use of it there was discussed with the help of Gareth Matthews work on the subject. In De Trinitate, Augustine uses the KKthesis for predominately epistemological purposes, and to elaborate his philosophy of mind. While much of Augustine's use of a KK-thesis in De Trinitate is consistent with his use of it in The City of God, in the latter Augustine adds a distinctively metaphysical and theological flavour to the KK-thesis itself. This shift in the use of the KK-thesis explains why, though on a first pass it may appear to be, it is not at all strange that Augustine would incorporate something so seemingly epistemological into a work that is so densely theological. 